\title{
Green Manufacturing in Agro Processing SMEs: Unraveling the Relationship Between Drivers and Their Effects on Adoption Practices in Ghana
}

\author{
William Gyasi-Mensah (Corresponding author) \\ Jiangsu University, China \\ Xuhua $\mathrm{Hu}$ \\ School of Finance and Economics, Jiangsu University, China \\ E-mail: xuhuahu@163.com
}

Received: October 30, 2019 Accepted: December 16, 2019 Published: December 19, 2019

doi: 10.5296/hrr.v4i1.15746

URL: https://doi.org/10.5296/hrr.v4i1.15746

\begin{abstract}
Environmental matters have been a subject of importance for national policy makers, ecology concerned groups and organizations. Green initiatives such as, green manufacturing has been seen to be a game changer in ensuring environmentally safe manufacturing by firms and nations while reaping the accompanying benefits. Investigations into motivating factors are still not fully carried out from all contexts. This research sought to find the effects that these drivers have on adoption of eco-friendly initiatives among small and medium enterprises from a developing country context. Structural Equation Model was adopted to analyze the data and verify the hypotheses. The outcomes indicate that financial and business benefits, competitor pressure and national environmental regulations positively influenced the adoption of green manufacturing adoption initiatives. Management and staff commitment influenced adoption slightly. These outcomes are vital to developing strategies for improving green practices implementation within firms for positive environmental and economic performance. Governments in developing nations especially Ghana will be well informed on which parts of the regulations to strengthen and enforce for improved environmental responsibility from Ghanaian agro processing small and medium enterprises and other businesses.
\end{abstract}

Keywords: Green manufacturing, SMEs, Drivers, Adoption practices, Agro processors 


\section{Introduction}

In past decades, the subject of sustainability and greening has attained heightened attention from both actors in business and the general society. The reason being that development in a sustainable manner has come to be seen as the appropriate approach towards achieving a fairer and prosperous world in which the natural resources, the environment and mankind can coexist and be protected for the benefit of coming generations (Evangelista et al., 2018).

The relevance of considering environmental aspects in the business context can be easily found in the current literature. Commitment to the environment has become a key variable in the contemporary competitive scenario (Molina-Azorin et al., 2015; Soubihia et al., 2015). Companies recognize the fact that environmental sustainability has implications for their competitive positions (Godinho Filho \& Ganga, 2016). There is a growing interest of the state, managers, customers, employees and academics regarding marketing strategies focused on the environment (Kumar \& Christodoulopoulou, 2014).

With the desire of developing economies and less industrial firms to grow into developed and industrialized ones, manufacturing (value addition) has been an inevitable approach towards achieving this objective. However, with the advent severe environmental deterioration, green manufacturing has received an increasing attention and it is being thought of as an essential path to achieve firm's environmental sustainability (Díaz-García et al., 2015; Le Van et al., 2019).

At present, the manufacturing industry has been shifting rapidly due to the increasing awareness of sustainable manufacturing activities. Thus, manufacturing firm have implemented various sustainable practices to reduce carbon footprint, remain competitive and as an answer to the global concern of environmental degradation. Some of the practices are known as Environmentally Conscious (Despeisse et al., 2012), Lean Manufacturing (Vienazindiene \& Ciarniene, 2013) and Green Manufacturing (Rehman \& Shrivastava, 2013). Scholars such as (Hart \& Dowell, 2011), focus on large corporations, as is implicit in the labels corporate social and environmental responsibility. Yet understanding why and how small and medium enterprises (SMEs) respond to environmental and social concerns is vital. SMEs play an important role in economic development and employment creation (Baumann-Pauly, Wickert, Spence, \& Scherer, 2013, Hamann et al., 2017).

In their work, Ampadu-Ameyaw and Omari (2015) expressed that, the Agro-food industry plays a fundamental role in the creation of income and employment opportunities in Ghana. It is important to sustain or improve the situation further. Despite the reality that these enterprises proffer opportunities for poverty reduction, food security and community development, they are not without challenges. Paramount among these challenges which have caught the attention of researchers in recent time is their negative effects on the environment. "Going green" has been one of the important ways that companies have dealt with environmental issues. To facilitate the adoption of green innovations, companies must consider the important drivers and antecedents in their businesses (El-Kassar, 2019).

As a country in Sub Saharan Africa that aims to achieve a middle income status, governments of Ghana over the years have been adopting several measures to achieve this objective. However, the negative effects that accompany the industrialization drive in the manufacturing 
sector due to production processes cannot be overlooked. Therefore, it calls for the application of methods that are environmentally friendly so as to make gains from such economic development measure, whilst protecting the environment.

Previous studies have been conducted on green related issues in Ghana's economy. For instance Braimah (2015) studied the impact of green brand awareness on consumer purchase decisions in Ghana, a focus on green purchasing; Amankwah-Amoah and Sarpong (2016) studied historical pathways to a green economy in which the emphasis was on the solar PV in Ghana; Kwarteng et al. (2016) in their studies delved into reverse logistics practices in Ghana with emphasis on the pharmaceutical industry.

This work uniquely and singularly draws attention to the manufacturing sector of Ghana, specifically the agro processing sub sector to fill a long left gap. Specifically, this study seeks to delve into factors that motivate the adoption of green manufacturing techniques and their influence on the adoption processes among small and medium firms in the agro processing industry in Ghana. The choice for the small and medium firms is because; they form the majority of processing firms in the Ghanaian agro processing landscape (Quartey and Darkwa 2015). With the outcomes of this study, government and industry players in the Ghanaian manufacturing landscape can fine-tune the state policies and managerial decisions for better environmental responsibility.

\section{Literature Review and Hypothesis}

In this research, a green manufacturing drivers and adoption model was developed that comprised six basic driver variable which are internal and external to the firms based on past literature and consultation with experts in this area of study. These include; management and staff green manufacturing commitment, Financial and business benefits; Firm's resources and consumer environmental awareness and demands; competitor influence; national environmental regulations and civil society group pressure respectively.

\subsection{Management and Staff Commitment and Green Manufacturing Practices Adoption}

A key driving force behind crafting an environmentally friendly business strategy is top management's sensitivity to green issues (Papagiannakis et al., 2014; Leonidou et al., 2015). This is because managers are responsible for, setting objectives, policies, and procedures that smooth the way toward proper adoption of green initiatives in the organization, as well as embarking on a more proactive approach to ecological problems that usually involves significant investments in both resources (e.g., technologies) and capabilities (e.g., relationship building) (Christensen et al., 2014); embodying environmental elements in key business processes (e.g., new product development, manufacturing process, market sensing) vital to achieving a market-oriented organization (Leonidou et al., 2017); and coordinating environmental initiatives, backing these initiatives by appointing the right people to supervise the firm's green activities, training employees to care about environmental issues, and motivating personnel to becoming more ecologically conscious through the provision of incentives (e.g., special awards) (Chen et al., 2015). According to Pinto and Allui (2016) among other studies, internal drivers have the highest impact on green practices. Top management commitment to environmentally-friendly actions has been observed to be traits in the absence of which green practices implementation becomes difficult or impossible 
(Bhanot et al., 2017).

From the viewpoint of Govindan et al. (2016), a firm's acceptance and implementation of green manufacturing strategies does not rely only on committed top managers but also on employees or staff awareness and support. They are more conversant with the methods of operations and are likely to have broader ideas about how to make the firm's process less harmful to the environment.

Hla: Management and staff commitment significantly influences the adoption of green manufacturing by SME agro processing firms.

\subsection{Firm's Resource and Green Manufacturing Practices Adoption}

Defining resources, the initial Resource-Based View (RBV) of strategy recognized resource only as anything which could be seen as a strength or weakness of a company (Wernerfelt, 1984). According to the RBV resources in comparison with products are basis for a firm's competitive advantage (Barney, 1991; 2017). In redefining resources, it was referred to as the input to the manufacturing process, including equipment, financing, skilled staff, knowledge resources, information technology and others that are crucial to firm's competitive advantage as they should be hard to be bought, copied or rare to access (Kozlenkova et al., 2014).

Organizational resources are tangible (e.g., finance, equipment, installations) or intangible (e.g., technical know-how, reputation, experience) assets controlled by the firm that help to design and implement strategies that will improve business performance (Lin \& Wu, 2014). Verbeke and Tung (2013) observed that from RBV context, resources are necessary to ensure the success of programs initiated in the business such as the introduction of green manufacturing practices. According to Adams et al. (2016) using the RBV, a firm that has invested in and so have access to technology, processes, systems, guiding blueprints and training can enhance its environmental competence and implementations such as adoption of eco-friendly practices. Although small firms, by default, have limited organizational resources, those that are in a position to make wise use of appropriate resources for environmentally friendly purposes are very likely to achieve superior performance (Klewitz and Hansen, 2014).

$H 1 b$ : Firm's resources significantly influence the adoption of green manufacturing by SME agro processing firms.

\subsection{Financial and Business Benefits, and Green Manufacturing Practices Adoption}

The economic urge pressures to adapt GM as it practices effect on the optimal resource and energy usage, which enhances the financial benefit of the manufacturer. Applying different approaches to minimize the total waste may mean using fewer raw materials per unit of product, reducing the weight and thickness of the packaging, and thus saving money for the firms (Zhu et al., 2019), an idea also shared by Barzegar et al. (2018). Recycling materials (e.g. metal scraps) within the firm can eliminate waste and minimize the SME's purchase of new raw materials. Arguments arise as to whether adoption of green strategy has benefits or it is simply buzzword. Research has revealed that many players are not aware of its benefits and even those that are aware are hesitant to change. Implementation of environmental management can provide several monetary and non-monetary benefits for organizations. The benefits of implementing green practices include costs saving (Johnson, 2015), gaining 
competitive advantage (Yaacob et al., 2016), increased organizational efficiency (Hillary, 2017), and enhanced company reputation (Park \& Kim, 2014). Various studies have thrown more light on how adding value to products creates returns. This research looks at it from how a firm's value addition process application in a green environment, creates an eco-friendly product that is likely to received sales from green product conscious consumers and earn the firm returns, while minimizing cost. Previous literature supports the theory that firms that implement green strategies show positive relationship in minimizing operational cost, and as a result save the firm financial resources, and improvement in their environmental performance (Esfahbodi et al., 2016). Again, according to Bossle et al. (2016) and del Mar Miras-Rodriguez et al. (2018), savings on expenditure has come to be known as one of the basic drivers of eco-friendly behaviors among firms. One of the possible avenues available to firms that need to or desire to cut expenditure is to engage in instituting green practices in their operational activities.

H1c: Financial and business benefits influence the adoption of green manufacturing by SME agro processing firms.

\subsection{Consumer Green Awareness and demand, and Green Manufacturing}

Several studies have discussed the impact of customer pressure on companies' decisions regarding environmental practices (Weng et al., 2015; Li et al., 2019). Customer expectations have become one of the most important factors influencing companies' environmental practices (Hsu et al., 2013). More and more customers now have strong concerns about the environment and prefer to purchase environmentally friendly products (Vishwakarma et al., 2018). Literature have shown that, the environmental consciousness of consumers is making them start to probe the effect of their purchased products on the environment, thereby expecting companies to take up some levels of green strategies in the design of their process and products (Kim et al., 2017 From an institutional theory perspective, business enterprises are forced to conform and be seen as legitimate and trustworthy through normative pressure (Daddi et al., 2016). Customers may refuse to buy products that damage the environment, which encourages companies to create green products ( $\mathrm{Li}$ et al., 2017). Firms in their effort to retain their consumers pay attention to feedbacks from consumers. Due to the increased awareness of current consumers, their environmental concerns forces firms to adopt eco-friendly strategies in their business activities. In Malaysia the environmental concerns of consumers is a primary source of normative pressure on producers to take up green strategies (Rohati et al., 2016). They have the capacity to indirectly affect the firm's environmental strategies (Weng et al., 2015).

H1d: Consumer green awareness and demand influence the adoption of green manufacturing by SME agro processing firms.

\subsection{Competitor Pressure and Green Manufacturing Practices Adoption}

Companies usually react and respond to the actions of their competitors. When competitors adopt new environmental practices, companies in the same industry will feel pressured to re-evaluate their current status regarding environmental responsibility and to decide whether to increase and/or improve the implementation of environmental practices (Hsu et al., 2013; Marano \& Kostova, 2016). In most environments where firms operate, there is usually 
pressure from the quarters of other competing firms in the same industry that pushes firms to embrace and implement green initiatives aimed at staying competitive in the market and gain the advantage therein (Iranmanesh et al., 2018).

With continuous pressure from competitors, many firms are forced to integrate design for environmental safety not only in their production process but also in their function as partners within the supply chain (Yenipazarli, 2019 According to institutional theory, factors that drive a firm to embrace green strategies can be grouped into coercive, normative and mimetic (Tachizawa et al., 2015). The mimetic form of drivers according to institutional theory becomes evident when firms imitate the actions of their competitors who they have observed to have been successful in the industry they operate in, with the aim of copying their approach to that success and subsequently gain legitimacy (Govindan, 2018).

Other studies opined that, out of pressure from competitors, many companies in Malaysia have allocated funding into reverse logistics such as recycling, refurbishment and remanufacturing (Mafini \& Loury-Okoumba, 2018). This was similar to the study of Eltayeb and Zailani, (2007) in which they observed that large firms in Malaysia working with other leading firms in developed economies have been compelled to not just focus on their direct suppliers but also their lower tier suppliers. In general, companies need to be aware of their competitors' offerings and industry norms to ensure that their innovation capabilities are similar to those of the rest of the industry. Therefore, to sustain competitive advantages, companies may imitate the environmental activities of competitors, especially the leaders in their industries (Galeazzo \& Klassen, 2015; Dangelico, 2016).

Hle: Competitor pressure significantly influences the adoption of green manufacturing by SME agro processing firms in Ghana.

\subsection{National Environmental Regulations and Green Manufacturing Practices Adoption}

State regulations and enforcement as a driving factor provides some form of environmental boundaries within which firms need to work to ensure sustainability in their operations. A number of studies have investigated the relationships between governmental regulations and environmental practices and have suggested that governmental pressure is one of the most significant external stakeholders, such as, (Wolf, 2013; Dixon-Fowler et al., 2017). Regulatory changes and enforcement of these changes by the government affect companies' actions regarding environmental management (Lin et al., 2014; Chu et al., 2018) and sustaining their business. Additionally, to compete globally, companies need to follow both global and local regulations to protect the environment. These official mechanisms take the form of standards, laws, procedures and incentives set by regulatory institutions to inspire firms to become environmentally responsible. Literature in the past supports the idea that requirements imposed by government and regulatory bodies provide ultimate incentives for firms to adopt green practices, especially in the supply chains (Madaan \& Mangla, 2015). Taking the dictates of institutional theory into consideration (del Mar Miras-Rodriguez et al. (2018), it throws more light on the fact that firms in their effort to be accepted by the public as legitimate are influenced by elements such as regulations that govern their activities. Legitimacy in this case refers to when firms embrace eco-friendly strategies that are seen by stakeholders as right and suitable (Roman, 2017). Fernando and Wah. (2017) examined advanced economies such as China and found out how coercive pressure through laws and 


\section{Macrothink Institute ${ }^{T M}$}

regulations enhanced environmental consciousness, thereby raising environmental management practices. The rigorousness of the regulations and firms' perceptions of the stringency of the regulations compels companies to actually implement environmental protection practices (Guoyou et al., 2013; Zailani et al., 2015). Moreover, the government's support and enforcement of the regulations has a significant impact on companies' environmental policies and adoption of green strategies (Singh et al., 2014; He et al., 2016), making this an important task to investigate.

H1f: National environmental regulations influence significantly influences the adoption of green manufacturing by SME agro processing firms in Ghana.

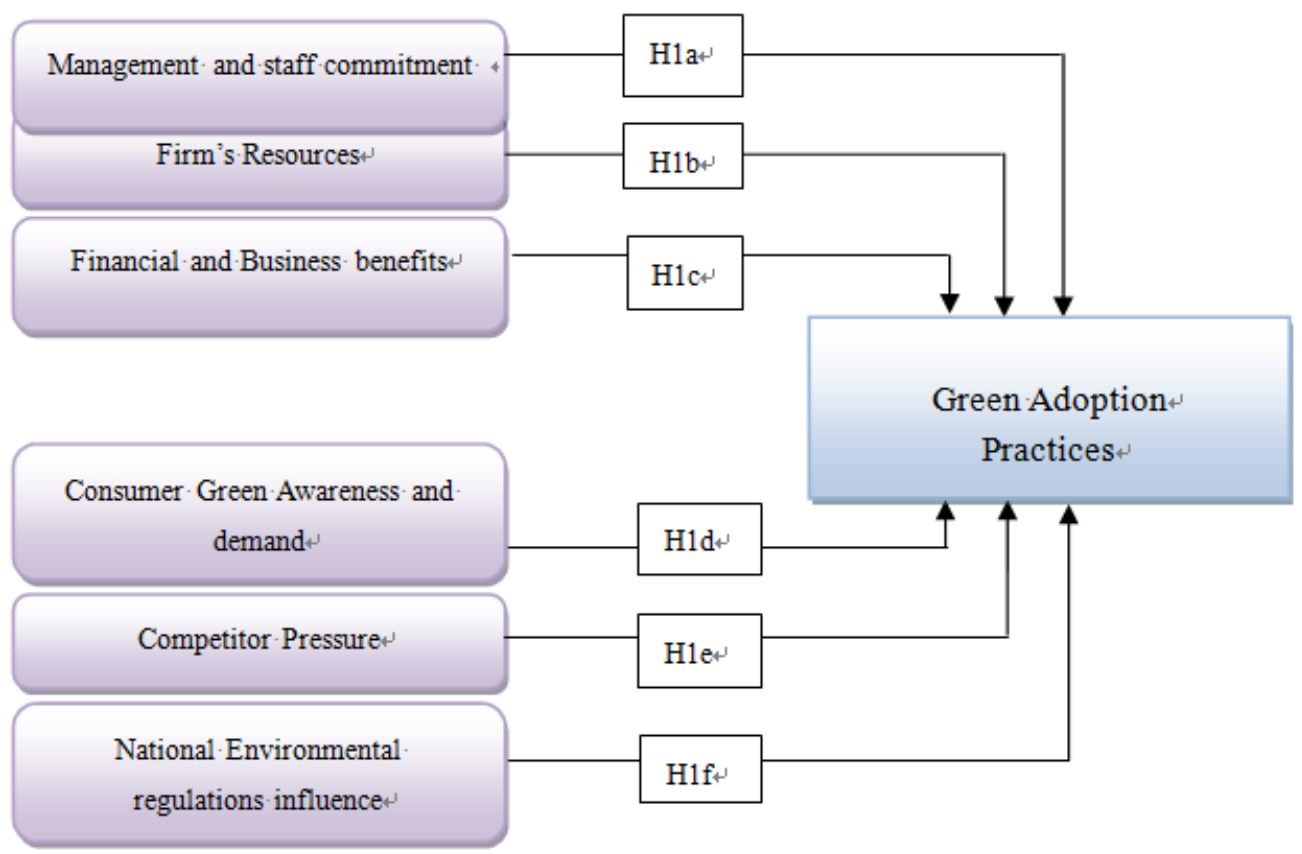

Figure 1. Conceptual model

\section{Methods and Results}

\subsection{Instrument Design}

A questionnaire survey approach was developed to investigate the proposed model. Based on a review of the literature, we designed a structured questionnaire with six primary constructs grouped under two headings. To ensure that the questionnaire would more precisely extract the data sought for the current study, a mini pilot survey with production managers and supervisors of 40 selected small and medium agro processing firms in Ghana was conducted. Respondents were asked to review and complete the questionnaire (i.e., as a pre-test) to identify ambiguities and suggest improvements to the questionnaire. An examination of the feedback led to further refinement and, eventually, the final version. All of the variables were measured on multiple item five-point Likert scale $(1=$ strongly disagree, $2=$ agree, 
$3=$ undecided, $4=$ disagree, 5 = strongly agree).

\subsection{Measurement of Constructs}

The survey questionnaire was in English. The method of collecting the survey information involved close contact between respondents and the researchers. The items adapted for this study were from past literature. Management and staff's

GM commitment was measured using 4 items from Govindan et al. (2015), Financial and Business Benefits using 5 items from Govindan et al. (2015), Dornfeld et al. (2013); Firm's resources was measured using 5 items from Leonidou et al. (2017), Consumer awareness and demand was measured with 5 items from Ramakrishnan et al. (2014), Govindan et al. (2015); Competitor influence or pressure was measured with 4 items from Sarkis et al. (2010), Tachizawa et al. (2015); National environmental regulations and Civil Society Groups' influence Zhu and Geng (2013), Abdul-Rashid et al. (2017).

\subsection{Sample and Data Collection}

The data used in this study comprised of survey questionnaire responses from the agro processing industry. Selecting this industry for this study was influenced by the fact that, they form the larger percentage of the manufacturing sector in Ghana, while their operations are viewed as having the most direct and observable impact on the environment. For the purpose of this study, the target respondents are simply the supervisors and the production managers of the target firms. This is due to the fact that, these are the officers perceived to have direct connection to the processes of manufacturing in these firms and is likely to oversee any change in methods of manufacturing as required.

Most of the questionnaires were dispatched to managers and production supervisors in these SMEs due to the fact that, most of these officers likely are much conversant with production and production strategies in their firms and so can respond appropriately to the questionnaire. Respondents received an envelope that contained a cover letter and a seven-page questionnaire. To motivate respondents, the researcher presented a green manufacturing branded souvenir China to each respondent. In addition, respondents were assured of the confidentiality of their responses and participation. The sample for this study was obtained from the National Board for Small Scale Industry (NBSSI) directory. The total sample size comprised small and medium firms within Ashanti, Eastern and Greater Accra regions of Ghana. We emphasized in the cover letter that participation in the survey is voluntary and the collected data will treated anonymously and will only be used only for research purposes. In all, 455 of questionnaire were received giving a response rate of $81.20 \%$ and 415 were usable for analysis.

\subsection{Analysis Procedure}

The structural equation modeling method is applied in the analysis and in applying the it, there were eleven unobserved latent variables: management and staff commitment (MSC); financial and business benefits (FBB); firm resources (FRS); consumer awareness and demand (CAD); competitor influence or pressure CIP); national environmental regulation influence (NEI); green management practices (GMP); green design practices (GDP); green purchasing practices (GPP); green promotion and selling (GPS); green logistics practices 
(GLP), and forty observed constructs - four measured MSC (MSC1-4); three measured FBB (FBB1-3); three measured FRS (FRS1-3); five measured CAD (CAD1-5); three measured CIP (CIP1-3); four measured NEI (NEI1-4); four measured GMP (GMP1-4); four measured GDP (GDP1-4); three measured GPP (GPP1-3); three measured GPS (GPS1-3); and four measured GLP (GLP1-4). It must be noted that, represented as the indicators of these eleven underlying unobserved variables are these forty observed variables.

Linked to each of these observed variables is a term known as error (ee1 - ee22), and with green adoption practices (GAP) implementation representing outcome variable, a residual term (ee23 - ee40). An error that is linked to an observed variable describes measurement error that presents how adequate they are in measuring the related underlying variables. The first order represents six elements (MSC, FBB, FRS, CAD, CIP, NEI) that represented independent variables and had error terms (ee1 - ee22); with each being seen as one level, or a single unidirectional arrow, opposite from the observed variables. The second order had five elements or variables (GMP, GDP, GPP, GPS, GLP) that represented dependent variable and had residual term associated (er1 - er5), with each representing one level or a single unidirectional arrow away from the observed variables, and measuring the related underlying variables.

\subsection{Results}

\subsubsection{Sample Description}

As far as this study is concerned, small and medium manufacturing firms were chosen as the preferred sample. The firms that were studied comprised agro processing firms based on their years of operations, staff size of the firm, environmental management status, environmental management unit status and environmental management policy status. As can be seen from Table 1, almost half of the firms $41 \%$ reported to have operated for between 10 to 20 years, whilst $32 \%$ of them reported to have operated for more than 20 years. It can be said that, majority of the sampled firms $73 \%$ had operated for more than 10 years, hence knowledgeable about their firms and operations

Table 1. Descriptive statistics

\begin{tabular}{|c|c|c|c|c|}
\hline Number & Variable & Category & Freq. & $\begin{array}{l}\text { Percentage } \\
(\%)\end{array}$ \\
\hline \multirow[t]{3}{*}{1} & \multirow{3}{*}{$\begin{array}{l}\text { Years of Operation } \\
(\mathrm{N}=415)\end{array}$} & $<10$ & 108 & $26.0 \%$ \\
\hline & & $10-20$ & 174 & $41.9 \%$ \\
\hline & & $>20$ & 133 & $32.0 \%$ \\
\hline \multirow[t]{2}{*}{2} & \multirow{2}{*}{$\begin{array}{l}\text { Staff Size of the Company } \\
(\mathrm{N}=415)\end{array}$} & Small & 270 & $65.1 \%$ \\
\hline & & Medium & 145 & $34.9 \%$ \\
\hline \multirow[t]{2}{*}{3} & \multirow{2}{*}{$\begin{array}{l}\text { Environmental management body } \\
\text { registration Status } \\
(\mathrm{N}=415)\end{array}$} & Registered & 275 & $66.3 \%$ \\
\hline & & Not Registered & 140 & $33.7 \%$ \\
\hline 4 & Environmental management unit & Have & 279 & $67.2 \%$ \\
\hline
\end{tabular}




\begin{tabular}{|c|c|c|c|c|}
\hline & arothink & & Human & $\begin{array}{r}\text { Resource Research } \\
\text { ISSN 1948-5441 } \\
\text { 2019, Vol. 3, No. } 1 \\
\end{array}$ \\
\hline \multirow{3}{*}{5} & $(\mathrm{~N}=415)$ & Do not Have & 136 & $32.8 \%$ \\
\hline & \multirow{2}{*}{$\begin{array}{l}\text { Environmental management policy } \\
(\mathrm{N}=415)\end{array}$} & Have & 263 & $63.4 \%$ \\
\hline & & Do not Have & 152 & $36.6 \%$ \\
\hline
\end{tabular}

\subsubsection{Reliability and Validity}

In testing the reliability of the recovered data, SPSS 19.0 was used. Reliability was ascertained using the Cronbach's alpha. Observation can be made from Table 2. that the values for each model is greater than 0.7 , an indication that the adopted scale possess a stable and acceptable reliability in consistence with techniques developed by Hair et al. (2014).

In addition, using related theoretical literature, validity of the questionnaire was supported. The validity of data was examined using average variance extracted (AVE) test all of which were above the acceptable value of 0.5 . It can be seen from Table 2. That all variables are reliable and valid for further analysis - these variables obtained valued higher or equal to the accepted threshold of 0.5 according to Hair et al. (2014).

Table 2. Construct items, factor loadings, AVEs and Cronbachs' alphas outcomes for variables

\begin{tabular}{|c|c|c|c|}
\hline Variable & Factor Loading & AVE & Cronbach's Alpha \\
\hline \multicolumn{4}{|c|}{ Management and Staff's GM Commitment (MSC) } \\
\hline MSC1 & 0.860 & 0.682 & 0.840 \\
\hline MSC2 & 0.816 & & \\
\hline MSC3 & 0.716 & & \\
\hline MSC4 & 0.639 & & \\
\hline \multicolumn{4}{|c|}{ Financial and Business Benefits (FBB) } \\
\hline FBB1 & 0.754 & 0.646 & 0.724 \\
\hline FBB2 & 0.651 & & \\
\hline FBB3 & 0.651 & & \\
\hline \multicolumn{4}{|c|}{ Firm's Resources (FRS) } \\
\hline FRS1 & 0.803 & 0.667 & 0.749 \\
\hline FRS2 & 0.680 & & \\
\hline FRS3 & 0.644 & & \\
\hline \multicolumn{4}{|c|}{ Consumer awareness and demand (CAD) } \\
\hline CAD1 & 0.749 & 0.550 & 0.781 \\
\hline CAD2 & 0.699 & & \\
\hline CAD3 & 0.686 & & \\
\hline CAD4 & 0.589 & & \\
\hline CAD5 & 0.582 & & \\
\hline
\end{tabular}




\begin{tabular}{llll}
\hline CIP1 & 0.815 & 0.679 & 0.761 \\
CIP2 & 0.714 & & \\
CIP3 & 0.634 & &
\end{tabular}

National environmental regulations and Civil Society Groups' influence (NEI)

$\begin{array}{ll}\text { NEI1 } & 0.755 \\ \text { NEI2 } & 0.695 \\ \text { NEI3 } & 0.659 \\ \text { NEI4 } & 0.562\end{array}$

Green Management (GMP)

$\begin{array}{llll}\text { GMP1 } & 0.632 & 0.505 & 0.772 \\ \text { GMP2 } & 0.577 & & \\ \text { GMP3 } & 0.569 & & \\ \text { GMP4 } & 0.554 & & \end{array}$

Green Design Practices (GDP)

$\begin{array}{llll}\text { GDP1 } & 0.853 & 0.588 & 0.767 \\ \text { GDP2 } & 0.677 & & \\ \text { GDP3 } & 0.586 & & \\ \text { GDP4 } & 0.568 & & \end{array}$

Green Purchasing (GPP)

$\begin{array}{llll}\text { GPP1 } & 0.762 & 0.599 & 0.788 \\ \text { GPP2 } & 0.634 & & \\ \text { GPP3 } & 0.506 & & \end{array}$

Green Promotion/Selling

$\begin{array}{llll}\text { GPS1 } & 0.871 & 0.650 & 0.811 \\ \text { GPS2 } & 0.803 & & \\ \text { GPS3 } & 0.790 & & \end{array}$

Green Logistics Practices (GLP)

\begin{tabular}{llll} 
GLP1 & 0.811 & 0.637 & 0.810 \\
GLP2 & 0.637 & & \\
GLP3 & 0.628 & & \\
GLP4 & 0.593 & & \\
\hline
\end{tabular}

\subsubsection{Structural Equation Model}

The Structural Equation Model could at the same time be used to assess the relationship among several latent variables, observed variables and also errors in the measures during the assessment process (Hair et al., 1998). It can also establish the nexus among several latent variables and tests the structure of their interaction. In this study, we employ SEM as a way of investigating the various proposed interactions.

The model fit indices were CMIN $\left(\mathrm{X}^{2}\right)=1691.069, \mathrm{DF}=710, \mathrm{CMIN} / \mathrm{DF}\left(\mathrm{X}^{2} / \mathrm{df}\right)=2.382$, $\mathrm{TLI}=0.781, \mathrm{CFI}=0.801$ and $\mathrm{RMSEA}=0.058$ and imply that the measurement model was acceptable. The outcomes are presented in Table 3. 
Table 3. Resulting green adoption practices model with estimated relationship and hypothesis testing

\begin{tabular}{|c|c|c|c|c|c|c|c|c|c|}
\hline \multicolumn{3}{|c|}{ Path of Influence } & \multirow{2}{*}{$\begin{array}{l}\text { Estimate } \\
-0.024\end{array}$} & \multirow{2}{*}{$\begin{array}{l}\text { S.E. } \\
0.044\end{array}$} & \multirow{2}{*}{$\begin{array}{l}\text { C.R. } \\
-0.548\end{array}$} & \multirow{2}{*}{$\begin{array}{c}\mathbf{P} \\
0.584\end{array}$} & \multirow{2}{*}{$\begin{array}{l}\text { Stand. } \\
\text { Weight } \\
-0.034\end{array}$} & \multirow{2}{*}{ Regress. } & \multirow{2}{*}{$\begin{array}{l}\text { Decision } \\
\text { Not } \\
\text { Supported }\end{array}$} \\
\hline GMP & $<-$ & MSC & & & & & & & \\
\hline GMP & $<-$ & FBB & 1.472 & 0.348 & 4.233 & $* * *$ & 0.613 & & Supported \\
\hline GDP & $<--$ & MSC & -0.097 & 0.044 & -2.176 & 0.03 & -0.119 & & Supported \\
\hline GPP & $<-$ & MSC & -0.064 & 0.036 & -1.776 & 0.076 & -0.106 & & $\begin{array}{l}\text { Not } \\
\text { Supported }\end{array}$ \\
\hline GPS & $<-$ & MSC & -0.029 & 0.027 & -1.076 & 0.282 & -0.075 & & $\begin{array}{l}\text { Not } \\
\text { Supported }\end{array}$ \\
\hline GLP & $<-$ & MSC & -0.086 & 0.054 & -1.605 & 0.109 & -0.093 & & $\begin{array}{l}\text { Not } \\
\text { Supported }\end{array}$ \\
\hline GDP & $<-$ & FBB & 2.103 & 0.454 & 4.629 & $* * *$ & 0.776 & & Supported \\
\hline GPP & $<-$ & FBB & 1.754 & 0.387 & 4.536 & $* * *$ & 0.862 & & Supported \\
\hline GPS & $<-$ & FBB & 0.933 & 0.224 & 4.159 & $* * *$ & 0.729 & & Supported \\
\hline GLP & $<-$ & FBB & 2.164 & 0.468 & 4.628 & $* * *$ & 0.697 & & Supported \\
\hline GMP & $<-$ & FRS & 0.004 & 0.057 & 0.064 & 0.949 & 0.004 & & $\begin{array}{l}\text { Not } \\
\text { Supported }\end{array}$ \\
\hline GDP & $<-$ & FRS & -0.022 & 0.058 & -0.375 & 0.708 & -0.022 & & $\begin{array}{l}\text { Not } \\
\text { Supported }\end{array}$ \\
\hline GPP & $<-$ & FRS & -0.039 & 0.047 & -0.829 & 0.407 & -0.052 & & $\begin{array}{l}\text { Not } \\
\text { Supported }\end{array}$ \\
\hline GPS & $<-$ & FRS & 0.004 & 0.034 & 0.109 & 0.913 & 0.008 & & $\begin{array}{l}\text { Not } \\
\text { Supported }\end{array}$ \\
\hline GLP & $<-$ & FRS & 0.124 & 0.069 & 1.787 & 0.074 & 0.108 & & $\begin{array}{l}\text { Not } \\
\text { Supported }\end{array}$ \\
\hline GMP & $<-$ & CAD & 0.014 & 0.071 & 0.191 & 0.848 & 0.012 & & $\begin{array}{l}\text { Not } \\
\text { Supported }\end{array}$ \\
\hline GDP & $<-$ & CAD & -0.049 & 0.072 & -0.68 & 0.497 & -0.038 & & $\begin{array}{l}\text { Not } \\
\text { Supported }\end{array}$ \\
\hline GPP & $<-$ & CAD & -0.076 & 0.059 & -1.289 & 0.197 & -0.08 & & $\begin{array}{l}\text { Not } \\
\text { Supported }\end{array}$ \\
\hline GPS & $<-$ & CAD & -0.022 & 0.042 & -0.509 & 0.611 & -0.036 & & $\begin{array}{l}\text { Not } \\
\text { Supported }\end{array}$ \\
\hline GLP & $<-$ & CAD & -0.068 & 0.087 & -0.789 & 0.43 & -0.047 & & $\begin{array}{l}\text { Not } \\
\text { Supported }\end{array}$ \\
\hline GMP & $<-$ & CIP & -0.112 & 0.052 & -2.135 & 0.033 & -0.145 & & Supported \\
\hline GDP & $<-$ & CIP & -0.155 & 0.055 & -2.805 & 0.005 & -0.177 & & Supported \\
\hline GPP & $<-$ & CIP & -0.058 & 0.044 & -1.312 & 0.19 & -0.088 & & $\begin{array}{l}\text { Not } \\
\text { Supported }\end{array}$ \\
\hline GPS & $<-$ & CIP & -0.087 & 0.034 & -2.568 & 0.01 & -0.21 & & Supported \\
\hline
\end{tabular}




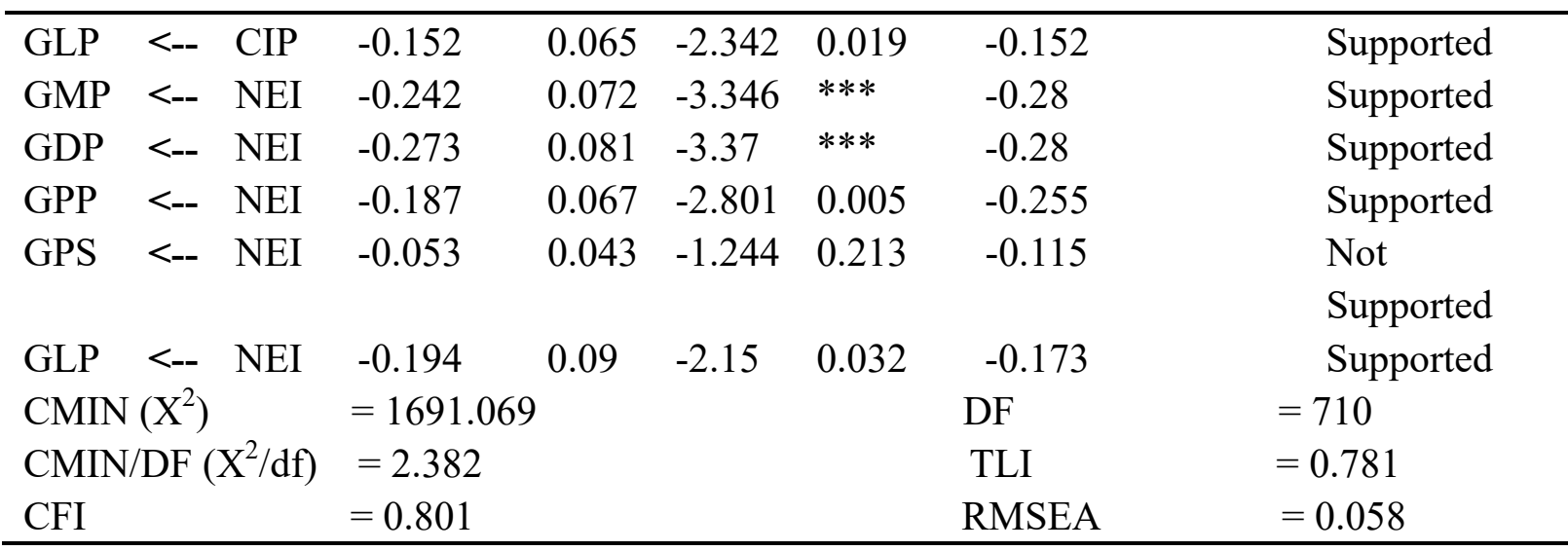

\subsubsection{Analysis}

As reported in Table 3, independent variable; management and staff commitment (MSC), financial and business benefit (FBB), firm resources (FRS), consumer awareness and demand (CAD), competitor influence/pressure (CIP) and national environmental regulations influence (NEI), and dependent variable green adoption practices (GAP) that is, green management practices (GMP), green design practices (GDP), green promotion/selling (GPS), green purchasing practices (GPS) and green logistics practices (GLP) are analyzed to know the relationship existing among them. Testing hypothesis was done through Structural Equation Model and using AMOS 24.0 which presents several positives as compared to other alternative testing mechanisms. Relationships between independent and dependent variables were carried out on constructs.

Table 3 shows that management and staff commitment marginally supports the hypothesis $1 \mathrm{a}$ to some extent as it has a significant effect on Green Design adoption with p-value of 0.03 at 0.05 significance level. It however failed to affect all other green adoption practices. It can be concluded that, MSC has an effect in green adoption practices but in a weak manner.

Financial and business benefit on the other significantly affected the green adoption practices as all p-values are below the statistically accepted 0.05 significance level. This lends support to Hypothesis $1 \mathrm{~b}$ that FBB has a significant effect on GAP.

Surprisingly, one of the studied constructs of firm resources significantly affected GAP as all p-values recorded are above the statistically significant level of 0.05 hence, hypothesis $1 \mathrm{c}$ wasn't supported.

Again, it can be observed from Table 3 that Consumer Awareness and Demand (CAD) does not support hypothesis $1 \mathrm{~d}$. In other words, there was no significant evidence of positive effect of it on GAP implementation. This is because all the P-values are above the accepted significant level of 0.05 , an implication that CAD has no effect on the probability of firms adopting green practices.

Compared to the other independent variables, competitor Influence/pressure was found to support hypothesis 1e. CIP was found to influence practices such as green management, green design, green promotion/selling and green logistics at P-values of 0.0033, 0.005, 0.01 and 0.019 respectively at 0.05 significant levels. However, CIP failed to affect green purchasing at the accepted significant level of 0.05 . 


\section{Macrothink Institute ${ }^{\mathrm{TM}}$}

A positive effect was established between National Environmental Regulations Influence (NEI) and implementation of GAP. Adoption practices such as GMP was positively influenced. GDP was equally influenced positively and significantly by NEI as observed from Table 3. GPP was also seen to be significantly influenced by NEI with p-value of 0.005 at 0.05 significance level. NEI again had a positively significant effect on GLP with a p-value of 0.032 at 0.05 significance level. However, a non-significant relation was observed between NEI and GPS which recorded a p-value of 0.213 at 0.05 significance level; an indication that NEI does not influence the adoption of green logistics. It can be concluded therefore that NEI supports our hypothesis $1 \mathrm{f}$.

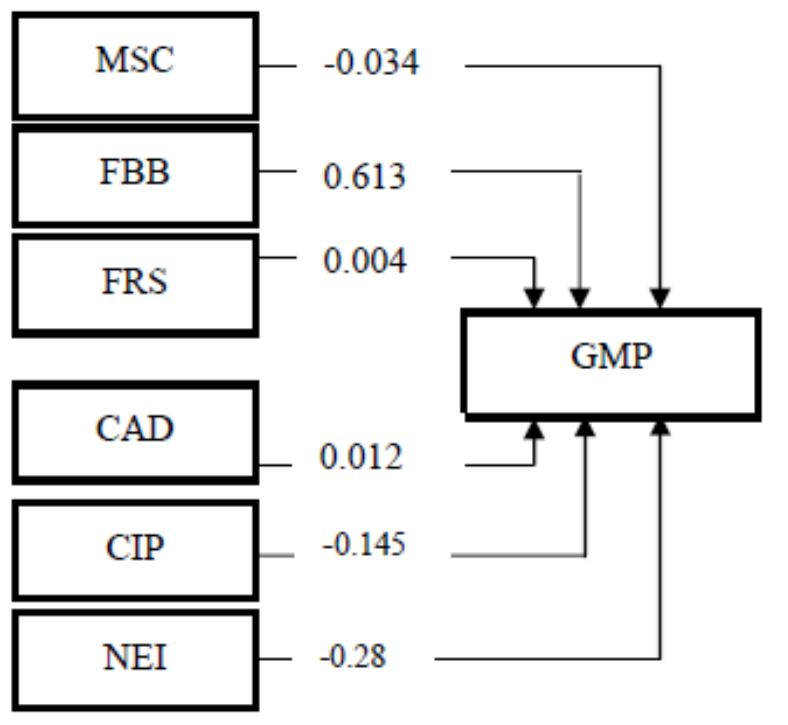

Figure 2. Drivers and green management practice

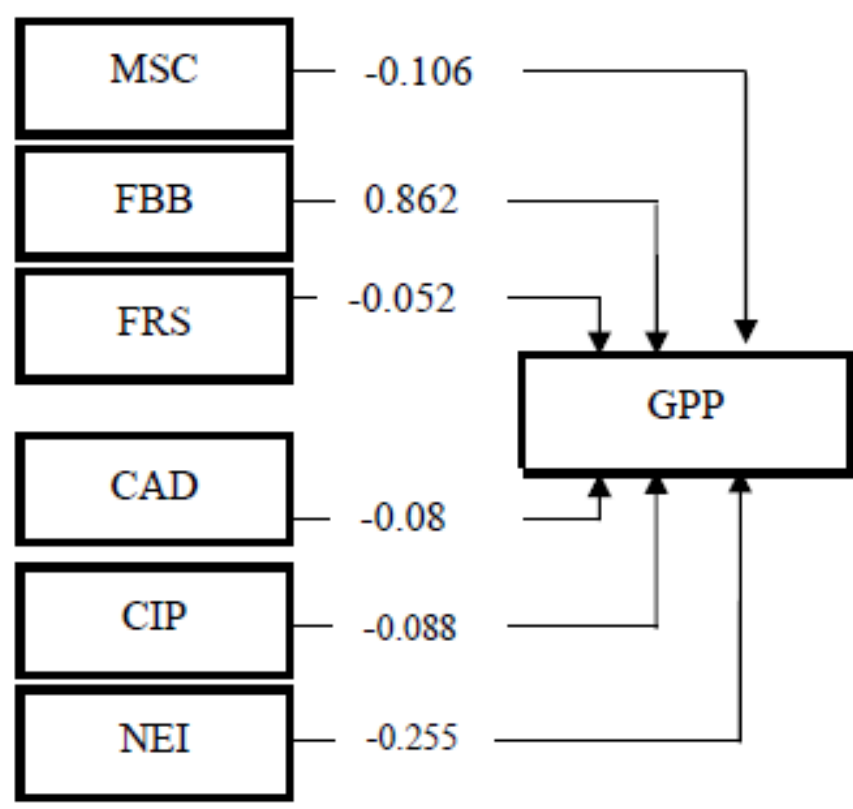

Figure 4. Drivers and green purchasing practices

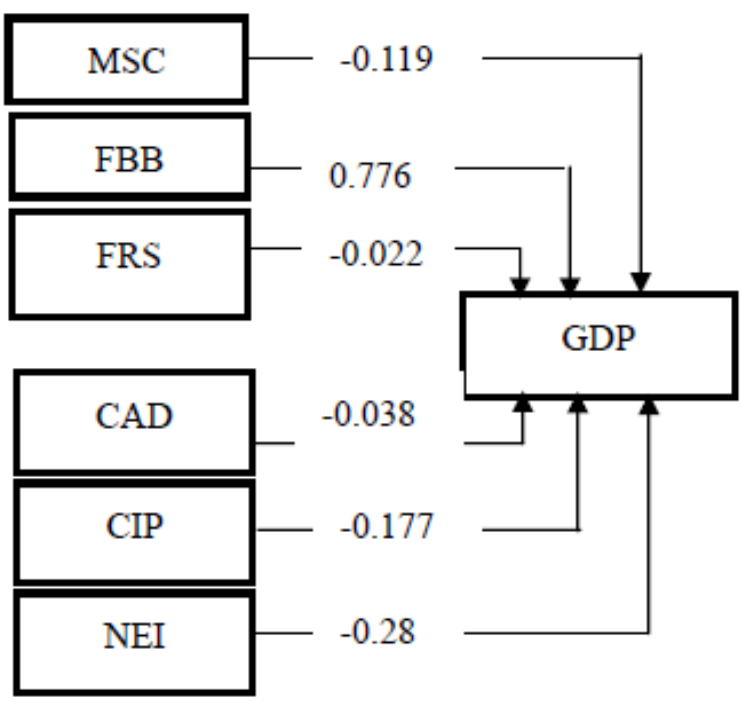

Figure 3. Drivers and green design practices

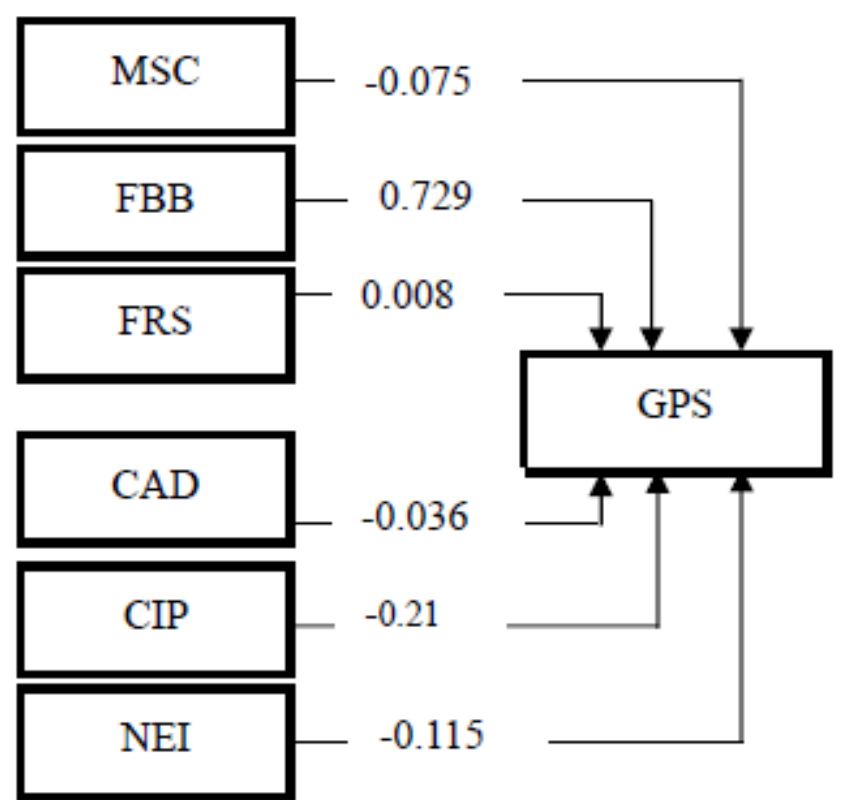

Figure 5. Drivers and green promotion/selling 
Figures 2 through 6 show the degree of influence of drivers on various green adoption initiatives. It can be seen that, MSC had weaker influence on all the green adoption practices, implying that it hardly influenced the firms to adopt green practices. Again, from the results it can be seen that, FBB had a relatively stronger positive significant degree of influence on the firms' adoption of green practices, implying that economic and business benefits such as profits, increased market share makes firms adopt eco-friendly initiatives. It can also be observed that, FRS did not have any major influence on firms' decision to go green. This implies despite a firm's resources, it may not adopt green practices but probably, only when complemented by other motivators, whilst it may also be due to the reason that cost of resources to implement green initiatives may deter them from adopting. CAD was also observed to have not actually influence decision to adopt four of the green practices. However, it had a positive insignificant effect on influencing adoption of GMP. The reason could be that, there is less awareness on environmental matters among many consumers within the research location; hence less pressure come from them to manufacturers to demand for green products. CIP was equally observed to have recorded low standard coefficients against the green adoption practices, although it had significant relationships with the practices, indicating that CIP despite its statistical significance was weak in influencing adoption of green practices. Finally, NEI as can be seen from Table 3 recorded statistical significance with green practices but showed weaker degree effects influencing on adoption of the green practices.

\section{Discussions}

It is evident from the analysis that though management and staff commitment (MSC) did not fully impact green adoption practices, it partially impacted it at one point such as green design of products and processes at p-value of 0.03 at 0.05 significant level by firms. This is in consistence with the study of Park and Kim (2014) which revealed that owner-manager attitudes significantly relates to green adoption. Also supporting our findings is that of Luthra et al. (2016) that concludes that green design adoption is dependent on firm's internal management, customer management and supplier management. However, all the other constructs were non significant in relation to the green practices at 0.05 significance level.

The study suggests that, financial and business benefit (FBB) is a major motivator for firms to integrate green adoption practices. A careful look at the results shows that, it significantly affects all the green adoption practices at 0.05 significance level. This outcome is in agreement with previous studies (eg. Ramakrishnan et al., 2015), that expressed that perceived benefits had positive and significant impact on green adoption practices such as green purchasing in SMEs.

Concerning the effect of firm resource drivers on green practices inclusion in firms, our results failed to validate its significance on adoption at 0.05 significance level. This non significance is consistent with previous study (eg. Aboelmaged, 2018). It was equally in agreement with other findings (eg. Routroy \& Kumar, 2016) which observed that, resources such as technology infrastructure and competencies have no influence on adoption of green practices. 
In this current study, it was observed that consumer awareness and demand (CAD) had no significant effect on adoption of green practices at 0.05 significance level. However, findings in other previous studies established a positive relationship between CAD and green practices. The current practices thus support the work of Weng et al. (2015). Again, it is contrary to other findings (eg. Aboelmaged, 2018) which found customer environmental pressure to affect green initiatives adoption.

Influence from competitors within the industry was also seen to have a positive effect on green adoption initiatives. Desire of firms to increase market share and profit, and stay in business are among the motivations for firms to implement green practices in their operations. Our results show that, competitor influence and pressure (CIP) had appreciable significance on green adoption t 0.05 significance level except against green promotion/selling that had a p-value of 0.19 at 0.05 significance level. The positive effect on green adoption supports the findings of Abdul-Rashid et al. (2017) that found similar results in their study on drivers for adoption of sustainable practices in Malaysia. Cai and Li (2018) also found that competitor pressure is a primary influencer of eco-innovation, thus showing consistence between their works and the current study. Again, the findings agrees with the outcome of Aboelmaged (2018) who found that competitive pressure impacts the decision to implement green initiatives in small and medium firms.

Institutional theory stipulates that coercive pressure compels firms o adopt environmentally friendly initiatives. Firms are expected to apply technologies that protect the environment and cut down environmental waste, while reporting their pollution emissions to appropriate quarters, failure to comply might attract legal penalty on the firm. From stakeholder theory context, firms are expected to operate to meet the expectations of stakeholders. From our results, national environmental regulations and CSO influence (NEI) shows a significant effect on green adoption practices in the firm. At a significance level of 0.05, NEI showed positive relationship with all adoption practices except against green promotion/selling which had a p-value of 0.213 at 0.05 significance level. The outcome is consistent with the outcome of Abdul-Aziz et al. (2018) that investigated the level of green initiative adoption and its effect on environmental performance in Malaysian listed firms. Similar agreement exist between our outcome and Luthra et al. (2014d) that stated that national and international environmental regulations have a significant impact on Indian auto firms adopting green purchasing initiatives. Our results again supports the results of Shankar et al. (2016) that validated the role of environmental laws and rules in affecting green adoption practices implementation in firms. However, our findings were in contrast with the outcomes of Aboelmaged (2018) which exhibited no positive between national environmental regulations and green adoption practices.

\section{Conclusion and Implications.}

On the whole, certain factors are necessary to drive or compel firms to adopt environmentally friendly practices that have minimal or no effect on the environment. Relationships exist between the motivators and the practices that are adopted among SMEs. Some of the drivers are internal to the firm whilst others are external to the firm. However, the empirical results from this study show that not all the perceived motivating factors actually have significant 
and positive effect on the integration of adoption practices in agro-processing SMEs in Ghana.

This research studies the motivators and the effect on adoption of green practices by analyzing empirically, data gathered from 415 small and medium enterprises engaged in agro-processing in Ghana. We add to the extant literature backed by framework that links our independent variables to the dependent variable. The study makes available practical implications to industry players and policy makers.

The study shows that MSC affected the adoption of GDP but failed to affect the adoption of GMP, GPP, GPS and GLP. The possible explanation could be that SMEs in Ghana are mostly sole proprietorship or family owned with no managerial structures to affect changes within the firm. However, with or without management, owners will be forced to design products that are eco-friendly when other factors such as competitors or national environment regulations, compel them to do so.

Secondly, financial and business benefits has been seen to be a strong driver for the adoption of green practices among agro-processing SMEs in Ghana as it was found to influence the adoption of all the eco-friendly practices observed in this study. Here again, the possible reason could be that every business person or investor has a profiteering motive and any SME owner in Ghana is no exception. Being convinced that adopting green practices will inure to the financial and general benefits of their firms, they will integrate these practices in their business.

Also, firm resources was seen not to influence agro-processing SMEs in Ghana to go green and the explanation to this could be lack of financing to procure green processing equipment, technology and training to meet this new trend, hence the reluctance to adopt.

The consumer in Ghana way probably not have enough awareness on the dangers of the production process of goods on the consumer and this end of life state of the environment, hence hardly do they demand eco-friendly agro product from manufacturers. In this case, manufactures hardly felt any pressure to include environmental standards in their products and processes, thus confirming why consumer awareness and demand may have failed to drive adoption of green practices in the research location and sample.

To survive in any industry requires the industry players to perform better than competitors or match them. When agro-processing SMEs in Ghana realize that their competitors have implemented certain initiatives that give them competitive advantage, results in this study shows they will also adopt same or similar initiatives to survive in the business environment, a possible explanation for the effect of competitor influence or pressure on adoption in this study.

The effect of national environmental regulations on green practices by firms has mostly been positive despite some contrary outcomes in some studies. The positive effect was evident in this current study. This could be linked to the fact that the laws and regulations on the environment compel them to do everything possible to supply eco-friendly products through eco-friendly processes. Knowing that breaching these regulations comes with significant losses including fines, legal action and possible revocation of operating license, firms are compelled to comply and adopt green practices for environmental safety. 
This study has some implications as well. From managerial content, SMEs and firms in agro-processing in Ghana should strive to upgrade and innovate on best initiatives on that will compel competitors to mimic some (mimetic pressure) for the good of the environment while reaping accompanying business benefits. Firms again need to position themselves to attract financing from investors to enable them finance required for integrating green initiatives in their operations.

Though SMEs and for that matter those in Ghana are mostly one man owned, owners must be educated to appreciate that they can still initiate eco-friendly practices into their operations. The non significance of customer awareness and pressure suggests that, civil society organizations and government need to sensitize the public on the dangers of environmental products and processes on the environment and the need to demand eco-friendly products and practices from manufacturers to compel them into adoption.

The significance of environmental regulations points, to the fact that policy makers in Ghana ought to regularly review, strengthen and enforce these regulations to check adherence by manufacturers to protect the environment. A careful look at the results shows that only two drivers (FBB and NEI) supported the adoption of green procurement or purchasing of materials from suppliers. Therefore, specific regulations if necessary must be made in respect of material purchasing to exert pressure on firms to also exert pressure on suppliers for eco-friendly suppliers along the supply chain.

Again, despite the findings and conclusions, it cannot be denied that this study may have some limitations that may necessitate further investigation into them. Our study used questionnaire and qualitative analysis to test the hypothesis on drivers. We identified six drivers for this study based on literature and expert opinion in the Ghanaian SME context. Other drivers may exist, and so succeeding studies should delve into these other drivers as related to other developing nations or Ghana.

Again, our sample was restricted to SMEs only. Therefore, large firms in the agro-processing industry were not captured. The motivations for adoption among these two firm types are likely to differ thereby necessitating further investigations.

Also, our research focused on manufacturing sector. However, service sector could also go green. Therefore, future research could investigate how the findings of this study could be applied for the service sector.

Lastly, our data were collected from three out of ten regions in Ghana. Future studies may expand the regional sample or even capture the entire country for a wider conclusion.

\section{References}

Abdul-Rashid, S. H., Sakundarini, N., Ariffin, R., \& Ramayah, T. (2017). Drivers for the adoption of sustainable manufacturing practices: A Malaysia perspective. International Journal of Precision Engineering and Manufacturing, 18(11), 1619-1631. https://doi.org/10.1007/s12541-017-0191-4

Aboelmaged, M. (2018). The drivers of sustainable manufacturing practices in Egyptian SMEs and their impact on competitive capabilities: A PLS-SEM model. Journal of Cleaner Production, 175, 207-221. https://doi.org/10.1016/j.jclepro.2017.12.053 
Adams, R., Jeanrenaud, S., Bessant, J., Denyer, D., \& Overy, P. (2016). Sustainability-oriented innovation: a systematic review. International Journal of Management Reviews, 18(2), 180-205. https://doi.org/10.1111/ijmr.12068

Amankwah-Amoah, J., \& Sarpong, D. (2016). Historical pathways to a green economy: the evolution and scaling-up of solar PV in Ghana, 1980-2010. Technological Forecasting and Social Change, 102, 90-101. https://doi.org/10.1016/j.techfore.2015.02.017

Ampadu-Ameyaw, R., \& Omari, R. (2015). Small-scale rural agro-processing enterprises in Ghana: Status, challenges and livelihood opportunities of women. Journal of Scientific Research \& Reports, 6(1), 61-72. https://doi.org/10.9734/JSRR/2015/15523

Bansal, P., \& Roth, K. (2000). Why Companies Go Green: A Model of Ecological Responsiveness. Academy of Management Journal, 43(4), 717-736. https://doi.org/10.5465/1556363

Barney, J. (1991). Firm Resources and Sustained Competitive Advantage. Journal of Management, 17(1), 99-120. https://doi.org/10.1177/014920639101700108

Barney, J. B. (2017). Resources, capabilities, core competencies, invisible assets, and knowledge assets: Label proliferation and theory development in the field of strategic management. The SMS Blackwell handbook of organizational capabilities, 422-426.

Barzegar, M., Ehtesham Rasi, R., \& Niknamfar, A. H. (2018). Analyzing the Drivers of Green Manufacturing Using an Analytic Network Process Method: A Case Study. International Journal of Research in Industrial Engineering, 7(1), 61-83.

Baumann-Pauly, D., Wickert, C., Spence, L. J., \& Scherer, A. G. (2013). Organizing corporate social responsibility in small and large firms: Size matters. Journal of business ethics, 115(4), 693-705. https://doi.org/10.1007/s10551-013-1827-7

Bhanot, N., Rao, P. V., \& Deshmukh, S. G. (2017). An integrated approach for analysing the enablers and barriers of sustainable manufacturing. Journal of cleaner production, 142, 4412-4439. https://doi.org/10.1016/j.jclepro.2016.11.123

Bossle, M. B., de Barcellos, M. D., Vieira, L. M., \& Sauvée, L. (2016). The drivers for adoption of eco-innovation. Journal of Cleaner production, 113, 861-872. https://doi.org/10.1016/j.jclepro.2015.11.033

Braimah, M. (2015). Green brand awareness and customer purchase intention. Management Science Letters, 5(10), 895-902. https://doi.org/10.5267/j.ms1.2015.8.007

Cai, W., \& Li, G. (2018). The drivers of eco-innovation and its impact on performance: Evidence from China. Journal of Cleaner Production, 176, 110-118. https://doi.org/10.1016/j.jclepro.2017.12.109

Chen, Y., Tang, G., Jin, J., Li, J., \& Paillé, P. (2015). Linking market orientation and environmental performance: The influence of environmental strategy, employee's environmental involvement, and environmental product quality. Journal of Business Ethics, 127(2), 479-500. https://doi.org/10.1007/s10551-014-2059-1

Christensen, L. J., Mackey, A., \& Whetten, D. (2014). Taking responsibility for corporate social responsibility: The role of leaders in creating, implementing, sustaining, or avoiding socially responsible firm behaviors. The Academy of Management Perspectives, 28(2), 
164-178. https://doi.org/10.5465/amp.2012.0047

Chu, Z., Xu, J., Lai, F., \& Collins, B. J. (2018). Institutional theory and environmental pressures: The moderating effect of market uncertainty on innovation and firm performance. IEEE Transactions on Engineering Management, 65(3), 392-403. https://doi.org/10.1109/TEM.2018.2794453

Daddi, T., Testa, F., Frey, M., \& Iraldo, F. (2016). Exploring the link between institutional pressures and environmental management systems effectiveness: An empirical study. Journal of environmental management, 183, 647-656. https://doi.org/10.1016/j.jenvman.2016.09.025

Dangelico, R. M. (2016). Green product innovation: where we are and where we are going. Business Strategy and the Environment, 25(8), 560-576. https://doi.org/10.1002/bse.1886

del Mar Miras-Rodriguez, M., Machuca, J. A., \& Escobar-Pérez, B. (2018). Drivers that encourage environmental practices in manufacturing plants: A comparison of cultural environments. Journal of Cleaner Production, 179, 690-703. https://doi.org/10.1016/j.jclepro. 2017.11.029

Despeisse, M., Mbaye, F., Ball, P. D., \& Levers, A. (2012). The emergence of sustainable manufacturing practices. Production Planning \& Control, 23(5), 354-376. http://dx.doi.org/ 10.1080/09537287.2011.555425

Díaz-García, C., González-Moreno, Á., \& Sáez-Martínez, F. J. (2015). Eco-innovation: insights from a literature review. Innovation, 17(1), 6-23. https://doi.org/10.1080/14479338. 2015.1011060

Dixon-Fowler, H. R., Ellstrand, A. E., \& Johnson, J. L. (2017). The role of board environmental committees in corporate environmental performance. Journal of Business Ethics, 140(3), 423-438.

Dornfeld, D., Yuan, C., Diaz, N., Zhang, T., \& Vijayaraghavan, A. (2013). Introduction to green manufacturing. Green Manufacturing (pp. 1-23). Springer, Boston, MA. http://dx.doi.org/10.1007/978-1-4419-6016-0_1

El-Kassar, A. N., \& Singh, S. K. (2019). Green innovation and organizational performance: the influence of big data and the moderating role of management commitment and HR practices. Technological Forecasting and Social Change, 144, 483-498. https://doi.org/10.1007/s10551-015-2664-7

Eltayeb, T., \& Zailani, S. (2007). The implementation of green supply chain management practices: a conceptual framework.

Esfahbodi, A., Zhang, Y., \& Watson, G. (2016). Sustainable supply chain management in emerging economies: Trade-offs between environmental and cost performance. International Journal of Production Economics, 181, 350-366. https://doi.org/10.1016/j.ijpe.2016.02.013

Evangelista, P., Santoro, L., \& Thomas, A. (2018). Environmental Sustainability in Third-Party Logistics Service Providers: A Systematic Literature Review from 2000-2016. Sustainability, 10(5), 1627. https://doi.org/10.3390/su10051627

Fernando, Y., \& Wah, W. X. (2017). The impact of eco-innovation drivers on environmental performance: Empirical results from the green technology sector in Malaysia. Sustainable Production and Consumption, 12, 27-43. https://doi.org/10.1016/j.spc.2017.05.002 
Galeazzo, A., \& Klassen, R. D. (2015). Organizational context and the implementation of environmental and social practices: what are the linkages to manufacturing strategy? Journal of Cleaner Production, 108, 158-168. https://doi.org/10.1016/j.jclepro.2015.06.053

Godinho Filho, M., Ganga, G. M. D., \& Gunasekaran, A. (2016). Lean manufacturing in Brazilian small and medium enterprises: implementation and effect on performance. International Journal of Production Research, 54(24), 7523-7545. https://doi.org/10.1080/ 00207543.2016 .1201606

Govindan, K. (2018). Sustainable consumption and production in the food supply chain: A conceptual framework. International Journal of Production Economics, 195, 419-431.

Govindan, K., Diabat, A., \& Shankar, K. M. (2015). Analyzing the drivers of green manufacturing with fuzzy approach. Journal of Cleaner Production, 96, 182-193.

Govindan, K., Muduli, K., Devika, K., \& Barve, A. (2016). Investigation of the influential strength of factors on adoption of green supply chain management practices: An Indian mining scenario. Resources, Conservation and Recycling, 107, 185-194.

Guoyou, Q., Saixing, Z., Chiming, T., Haitao, Y., \& Hailiang, Z. (2013). Stakeholders' influences on corporate green innovation strategy: a case study of manufacturing firms in China. Corporate Social Responsibility and Environmental Management, 20(1), 1-14.

Hair Jr. J. F., Sarstedt, M., Hopkins, L., \& Kuppelwieser, G. V. (2014). Partial least squares structural equation modeling (PLS-SEM) An emerging tool in business research. European Business Review, 26(2), 106-121. https://doi.org/10.1108/EBR-10-2013-0128

Hair, J. F., Anderson, R. E., Tatham, R. L., \& Black, W. C. (1998). Multivariate data analysis New Jersey: Prentice-Hall.

Hamann, R., Smith, J., Tashman, P., \& Marshall, R. S. (2017). Why do SMEs go green? An analysis of wine firms in South Africa. Business \& society, 56(1), 23-56. https://doi.org/10.1177/0007650315575106

Hart, S. L., \& Dowell, G. (2011). Invited editorial: A natural-resource-based view of the firm: Fifteen years after. Journal of management, 37(5), 1464-1479. https://doi.org/10.1177/ 0149206310390219

He, Z. X., Xu, S. C., Shen, W. X., Long, R. Y., \& Chen, H. (2016). Factors that influence corporate environmental behavior: empirical analysis based on panel data in China. Journal of Cleaner Production, 133, 531-543. https://doi.org/10.1016/j.jclepro.2016.05.164

Hillary, R. (2017). Small and medium-sized enterprises and environmental compliance: attitudes among management and non-management. Small and Medium-Sized Enterprises and the Environment (pp. 49-60). Routledge. https://doi.org/10.4324/9781351282840

Hsu, C.-C., Tan, K. C., Zailani, S. H. M., \& Jayaraman, V. (2013) Supply chain drivers that foster the development of green initiatives in an emerging economy. Int. J. Oper. Prod. Manag., 33, 656-688. https://doi.org/10.1108/IJOPM-10-2011-0401

Iranmanesh, M., Fayezi, S., Hanim, S., \& Hyun, S. S. (2018). Drivers and outcomes of eco-design initiatives: a cross-country study of Malaysia and Australia. Review of Managerial Science, 1-22. https://doi.org/10.1007/s11846-018-0282-3

Johnson, M. P. (2015). Sustainability management and small and medium-sized enterprises: 


\section{Mll Macrothink}

Managers' awareness and implementation of innovative tools. Corporate Social Responsibility and Environmental Management, 22(5), 271-285. https://doi.org/10.1002/ csr.1343

Kim, H., Park, K., \& Ryu, D. (2017). Corporate environmental responsibility: A legal origins perspective. Journal of business ethics, 140(3), 381-402. https://doi.org/10.1007/s10551 $-015-2641-1$

Klewitz, J., \& Hansen, E. G. (2014). Sustainability-oriented innovation of SMEs: a systematic review. Journal of Cleaner Production, 65, 57-75. https://doi.org/10.1016/ j.jclepro.2013.07.017

Kozlenkova, I. V., Samaha, S. A., \& Palmatier, R. W. (2014). Resource-based theory in marketing. Journal of the Academy of Marketing Science, 42(1), 1-21. https://doi.org/ 10.1007/s11747-013-0336-7

Kumar, V., \& Christodoulopoulou, A. (2014). Sustainability and branding: An integrated perspective. Industrial Marketing Management, 43(1), 6-15. https://doi.org/10.1016/ j.indmarman.2013.06.008

Kwarteng, A., Dadzie, S. A., \& Famiyeh, S. (2016). Sustainability and competitive advantage from a developing economy. Journal of Global Responsibility, 7(1), 110-125. https://doi.org/10.1108/JGR-02-2016-0003

Le Van, Q., Viet Nguyen, T., \& Nguyen, M. H. (2019). Sustainable development and environmental policy: The engagement of stakeholders in green products in Vietnam. Business Strategy and the Environment, 28(5), 675-687. https://doi.org/10.1002/bse.2272

Leonidou, L. C., Christodoulides, P., Kyrgidou, L. P., \& Palihawadana, D. (2017). Internal drivers and performance consequences of small firm green business strategy: The moderating role of external forces. Journal of Business Ethics, 140(3), 585-606. https://doi.org/ 10.1007/s10551-015-2670-9

Leonidou, L. C., Fotiadis, T. A., Christodoulides, P., Spyropoulou, S., \& Katsikeas, C. S. (2015). Environmentally friendly export business strategy: Its determinants and effects on competitive advantage and performance. International Business Review, 24(5), 798-811. https://doi.org/10.1016/j.ibusrev.2015.02.001

Li, D., Zheng, M., Cao, C., Chen, X., Ren, S., \& Huang, M. (2017). The impact of legitimacy pressure and corporate profitability on green innovation: Evidence from China top 100. Journal of Cleaner Production, 141, 41-49. https://doi.org/10.1016/j.jclepro.2017.04.031

Li, Y., Ye, F., Dai, J., Zhao, X., \& Sheu, C. (2019). The adoption of green practices by Chinese firms: Assessing the determinants and effects of top management championship. International Journal of Operations \& Production Management, 39(4), 550-572. https://doi.org/10.1108/IJOPM-12-2017-0753

Lin, H., Zeng, S. X., Ma, H. Y., Qi, G. Y., \& Tam, V. W. (2014). Can political capital drive corporate green innovation? Lessons from China. Journal of Cleaner Production, 64, 63-72. https://doi.org/10.1016/j.jclepro.2013.07.046

Lin, Y., \& Wu, L. Y. (2014). Exploring the role of dynamic capabilities in firm performance under the resource-based view framework. Journal of business research, 67(3), 407-413. 
https://doi.org/10.1016/j.jbusres.2012.12.019

Luthra, S., Garg, D., \& Haleem, A. (2016). The impacts of critical success factors for implementing green supply chain management towards sustainability: an empirical investigation of Indian automobile industry. Journal of Cleaner Production, 121, 142-158. https://doi.org/10.1016/j.jclepro.2016.01.095

Luthra, S., Garg, D., Haleem, A. (2014d). Greening the supply chain using SAP-LAP analysis: A case study of an auto ancillary company in India. International Journal of Business Excellence, 7(6), 724-746. https://doi.org/10.1504/IJBEX.2014.065505

Madaan, J., \& Mangla, S. (2015). Decision modeling approach for eco-driven flexible green supply chain. Systemic flexibility and business agility (pp. 343-364). Springer, New Delhi. https://doi.org/10.1007/978-81-322-2151-7_21

Mafini, C., \& Loury-Okoumba, W. V. (2018). Extending green supply chain management activities to manufacturing small and medium enterprises in a developing economy. South African Journal of Economic and Management Sciences, 21(1), 1-12. https://doi.org/10.4102/ sajems.v21i1.1996

Marano, V., \& Kostova, T. (2016). Unpacking the institutional complexity in adoption of CSR practices in multinational enterprises. Journal of Management Studies, 53(1), 28-54. https://doi.org/10.1111/joms.12124

Molina-Azorín, J. F., Tarí, J. J., Pereira-Moliner, J., Lopez-Gamero, M. D., \& Pertusa-Ortega, E. M. (2015). The effects of quality and environmental management on competitive advantage: A mixed methods study in the hotel industry. Tourism Management, 50, 41-54. https://doi.org/10.1016/j.tourman.2015.01.008

Papagiannakis, G., Voudouris, I., \& Lioukas, S. (2014). The road to sustainability: Exploring the process of corporate environmental strategy over time. Business Strategy and the Environment, 23(4), 254-271. https://doi.org/10.1002/bse.1781

Park, J., \& Kim, H. J. (2014). The Impact of Top Management's Environmental Attitudes on Hotel Companies' Environmental Management. Journal of Hospitality \& Tourism, 38(1), 95-115. https://doi.org/10.1177/1096348012452666

Park, J., Jeong Kim, H., \& McCleary, K. W. (2014). The impact of top management's environmental attitudes on hotel companies' environmental management. Journal of Hospitality \& Tourism Research, 38(1), 95-115. https://doi.org/10.1177/1096348012452666

Pinto, L., \& Allui, A. (2016). An Analysis of Drivers and Barriers for Sustainability Supply Chain Management Practices. Journal of Asia Entrepreneurship and Sustainability, 12(2), 197.

Quartey, E. T., \& Darkwah, S. (2015). Factors affecting the use of modern technologies in agro processing in Ghana. Academia Journal of Agricultural Research, 3(7), 99-115.

Ramakrishnan, P., Haron, H., \& Goh, Y. N. (2015). Factors influencing green purchasing adoption for small and medium enterprises (SMEs) in Malaysia. International Journal of Business and Society, 16(1). https://doi.org/10.33736/ijbs.552.2015

Ramanathan, R., Poomkaew, B., \& Nath, P. (2014). The impact of organizational pressures on environmental performance of firms. Business Ethics: A European Review, 23(2), 169-182. 
https://doi.org/10.1111/beer.12042

Rehman, M. A. A., \& Shrivastava, R. L. (2013). Green manufacturing (GM): Past, present and future (a state of art review). World Review of Science, Technology and Sustainable Development, 10(1-2-3), 17-55. https://doi.org/10.1504/WRSTSD.2013.050784

Rohati, S., Norlida, M. N., \& Jamal, A. S. (2016). Factors Influencing ISO 14001 Firm's Perceived Environmental Performance in Malaysia. ASEAN Journal on Science and Technology for Development, 33(1), 18-36. https://doi.org/10.29037/ajstd.3

Roman, A. V. (2017). Institutionalizing sustainability: A structural equation model of sustainable procurement in US public agencies. Journal of Cleaner Production, 143, 1048-1059. https://doi.org/10.1016/j.jclepro.2016.12.014

Routroy, S., \& Kumar, C. S. (2016). An approach to develop green capability in manufacturing supply chain. International Journal of Process Management and Benchmarking, 6(1), 1-28. https://doi.org/10.1504/IJPMB.2016.073322

Sarkis, J., Gonzalez-Torre, P., \& Adenso-Diaz, B. (2010). Stakeholder pressure and the adoption of environmental practices: The mediating effect of training. Journal of Operations Management, 28(2), 163-176. https://doi.org/10.1016/j.jom.2009.10.001

Shankar, K. M., Kumar, P. U., \& Kannan, D. (2016). Analyzing the drivers of advanced sustainable manufacturing system using AHP approach. Sustainability, 8(8), 824. https://doi.org/10.3390/su8080824

Singh, N., Jain, S., \& Sharma, P. (2014). Determinants of proactive environmental management practices in Indian firms: an empirical study. Journal of cleaner production, 66, 469-478. https://doi.org/10.1016/j.jclepro.2013.11.055

Soubihia, D. F., Jabbour, C. J. C., \& Sousa Jabbour, A. B. L. (2015). Green manufacturing: Relationship between adoption of green operational practices and green performance of ISO 9001 certified firms. International Journal of Precision Engineering and Manufacturing-Green Technology, 2(1), 95-98. https://doi.org/10.1007/s40684-015-0012-0

Tachizawa, E. M., Gimenez, C., \& Sierra, V. (2015). Green supply chain management approaches: drivers and performance implications. International Journal of Operations \& Production Management, 35(11), 1546-1566. https://doi.org/10.1108/IJOPM-01-2015-0023

Verbeke, A., \& Tung, V. (2013). The future of stakeholder management theory: A temporal perspective. Journal of Business Ethics, 112(3), 529-543. https://doi.org/10.1007/s10551 $-012-1276-8$

Vienazindiene, M., \& Ciarniene, R. (2013). Lean manufacturing implementation. Economics and Management, 18(2), 366-373. https://doi.org/10.5755/j01.em.18.2.4732

Vishwakarma, A. K., Nema, A. K., \& Sangle, S. (2018). Study of determinants of proactive environmental strategies in India's power sector. Journal of cleaner production, 194, 43-53. https://doi.org/10.1016/j.jclepro.2018.05.135

Weng, H-H, Chen, J-S., \& Chen, P-C. (2015). Effects of Green Innovation on Environmental and Corporate Performance: A Stakeholder Perspective. Sustainability, 7(5), 4997-5026. https://doi.org/10.3390/su7054997

Wernerfelt, B. (1984). A resource-based view of the firm. Strategic management journal, 5(2), 
171-180. https://doi.org/10.1002/smj.4250050207

Wolf, J. (2013). Improving the sustainable development of firms: the role of employees. Business Strategy and the Environment, 22(2), 92-108. https://doi.org/10.1002/bse.1731

Yaacob, M. R., Zain, N. F. M., Zakaria, M. N., \& Ismail, M. (2016). Environmental Management Practices in Small Batik Industry in Kelantan, Malaysia. Environmental Management, 7(13).

Yenipazarli, A. (2019). Incentives for environmental research and development: Consumer preferences, competitive pressure and emissions taxation. European Journal of Operational Research, 276(2), 757-769. https://doi.org/10.1016/j.ejor.2019.01.037

Zailani, S., Govindan, K., Iranmanesh, M., Shaharudin, M. R., \& Chong, Y. S. (2015). Green innovation adoption in automotive supply chain: the Malaysian case. Journal of Cleaner Production, 108, 1115-1122. https://doi.org/10.1016/j.jclepro.2015.06.039

Zhu, Q., \& Geng, Y. (2013). Drivers and barriers of extended supply chain practices for energy saving and emission reduction among Chinese manufacturers. Journal of Cleaner Production, 40, 6-12. https://doi.org/10.1016/j.jclepro.2010.09.017

Zhu, X. Y., Zhang, H., \& Jiang, Z. G. (2019). Application of green-modified value stream mapping to integrate and implement lean and green practices: A case study. International Journal of Computer Integrated Manufacturing, 1-16. https://doi.org/10.1080/0951192X.2019.1667028

\section{Glossary}

AMOS Analysis of a moment structure

AVE Average Variance Extracted

CAD Consumer awareness and demand

CIP Competitor influence or pressure

FBB Financial and Business Benefits

FRS Firm's Resources

GAP Green Adoption Practices

GDP Green Design Practices

GLP Green Logistics Practices

GM Green manufacturing

GMP Green Management Practice

GPP Green Purchasing Practice

GPS Green Promotion/Selling 
MSC Management and Staff's GM Commitment

NBSSI National Board for Small Scale Industry

NEI National environmental regulations influence

RBV Resource-Based View

SME $\quad$ Small and Medium Enterprise

SPSS Statistical Package for the Social Sciences

\section{Appendix 1}

SECTION A: Firm's Basic Information

Please answer the following questions concerning information about your organization.

1. How long your firm has been operating?
A. $<10$ years
B. $10-20$ years
C. $>20 \mathrm{yrs}$

2. What is the size of the staff of your company?
A. $<10$
B. $10-20$
C. $20-30$
D. $>30$

3. Is your firm registered with any environmental management body?
A. Yes
B. No

4. Does your firm have environmental management unit?
A. Yes
B. No

5. Does your firm have an environmental management policy?
A. Yes
B. No

B. SECTION B: Anticipated drivers of Green manufacturing (GM) integration in a firm.

Please rate the following factors which drive your firm to integrate environmentally friendly manufacturing on a scale from 1 to 5 ; where ' 1 ' means non driver and ' 5 ' means very high driver by $\sqrt{ }$ mark in the appropriate box.

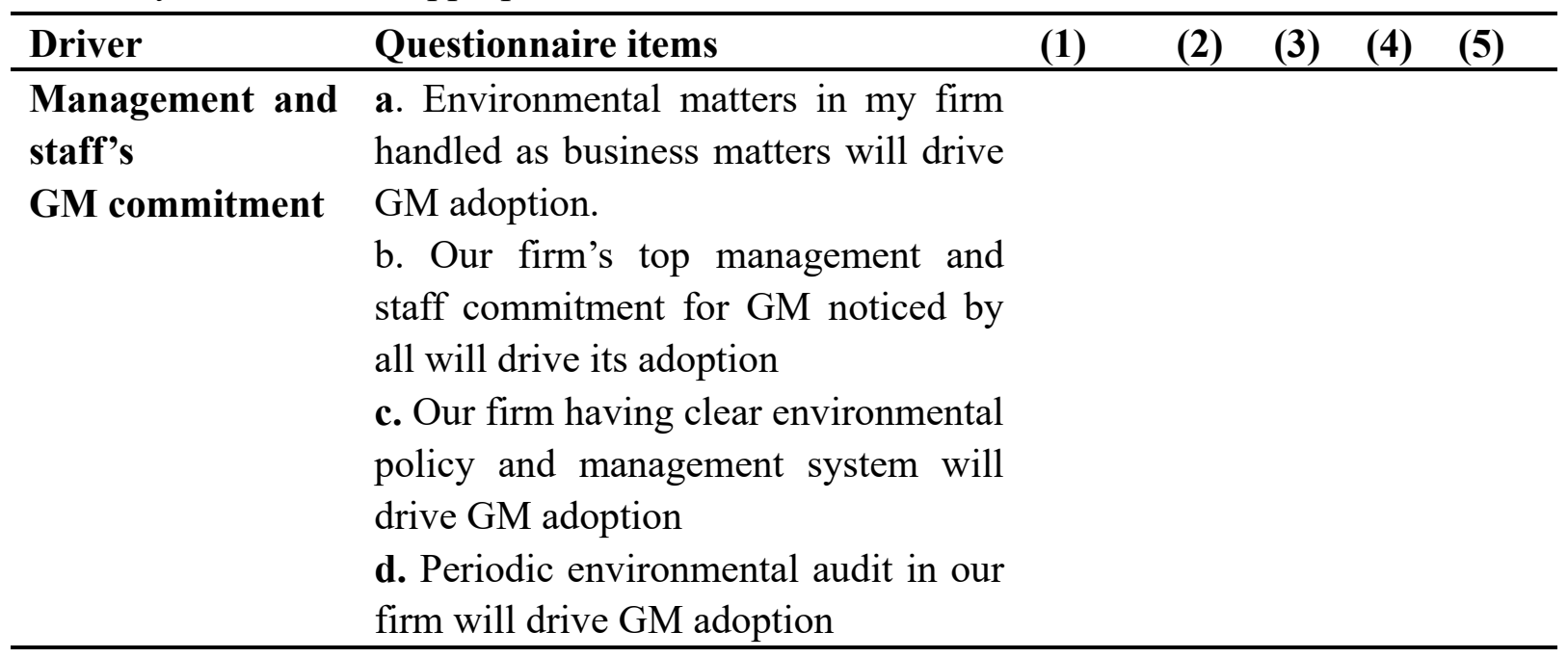


Financial and a. Green direct investment by

Business Benefits investors will drive our firm's GM adoption

b. Expectation of green products' high marketability will drive GM adoption in our firm

c. Cost effectiveness of green processes will drive our firm's GM adoption

Firm's Resources a. Trained and skilled employees in our firm will drive GM adoption

b. Expectations of green financial institutions will drive GM adoption.

c. Availability of green technology in our firm will drive GM adoption.

Consumer awareness demand

Competitor influence pressure

National environmental a. Desire to gain public recognition and and customer goodwill will drive GM adoption in our firm

b. Customer expectations of our firm to meet environmental protection regulations will drive GM adoption

c. Readiness of consumers to pay more for green products will drive GM adoption

d. Pressure from suppliers demanding green standards from our firm will drive GM adoption

e. Customer awareness and demand for green products will drive our firm's GM adoption

a. Competitive advantage over or conventional manufacturing competitors will influence our firm's GM adoption.

b. Manufacturing of green products by competitors will influence are firm's GM adoption

d. Business association with green competitor firms will influence our firm's GM adoption

a. Imposition of fines, penalties and legal costs influences our firm's 
regulations and compliance to eco-friendly regulations

Civil Society and adoption of GM.

Groups'influence b. Strict environmental and manufacturing regulations will influence our firm's GM adoption

c. Demand from community for safer and cleaner environment will drive our firm's GM adoption

d. Pressure and creation of awareness by civil societies, green movement and NGOs will influence our firm's GM adoption

Green

Management

Practice (GMP)
Green Design Practices (GDP)

a. Environmental collaboration with customers

b. Total quality environment management practices

Implementation

c. Reward \& incentives for environmental initiatives taken by employees

d. Commitment \& support for green practices from top management

a. Substitution of polluting \& hazardous material/components

b. Design for recycling

c. Green product development practices

d. Design for environment

Green

Purchasing

Practices (GPP)

a. Providing design specification to suppliers/vendors including environmental requirements

b. Purchasing products that have environmentally friendly attribute (recyclable content, nontoxic etc.)

c. Motivation for environmental friendly suppliers/vendors

Green a. Sale of excess inventories/materials

Promotion/Selling b. End of life product management (GPS) c. Sale of scrap \& used material 
Green Logistics a. Remanufacturing of components or

Practices (GLP) products

b. Reusing/recycling of materials or components or products

c. Use of environmental friendly transportation

d. Use of environmental friendly distribution

\section{Copyright Disclaimer}

Copyright for this article is retained by the author(s), with first publication rights granted to the journal.

This is an open-access article distributed under the terms and conditions of the Creative Commons Attribution license (http://creativecommons.org/licenses/by/3.0/). 